\title{
Russian documents set out 'tectonic weapon' research
}

Moscow. The first official details have emerged in Moscow of ambitious research into 'tectonic warfare' carried out by the former Soviet Union and subsequently by the government of Russia, and involving attempts to stimulate 'artificial' earthquakes as weapons of destruction.

According to documents obtained by the newspaper Moscow News, two research programmes, the first known as 'Mercury' and the second as 'Volcano', were aimed at creating new earthquake epicentres by using underground nuclear explosions.

Geophysicists are aware that impending earthquakes may be triggered by underground nuclear explosions. But Western geophysicists remain sceptical about tectonic warfare and have all but abandoned research after two unsuccessful phases of activity in the 1960s and 1980s, says Roger Clark, a lecturer in geophysics at the University of Leeds.

Clark is not at all surprised that the Russians tried to create earthquakes and control their location electromagnetically, however. "This sort of science is very much part of their heritage. We don't think it is impossible, or wrong, but past experience suggests it is very, very unlikely."

The programme, which was secretly launched by the Communist rulers of the former Soviet Union in 1987, and has been unofficially known to Western geophysicists for several years, is now believed to have been abandoned. It would certainly contravene the terms of the Comprehensive Test Ban Treaty, which Russia signed at the United Nations in Geneva last month.

The Mercury project was launched in the former Soviet republic of Azerbaijan, but came to a halt when the republic became independent. It was superseded by the Volcano project. Three underground nuclear tests are believed to have taken place at sites in Kyrgyzstan.

According to the documents, the Mercury project was launched by a secret decree of the Central Committee of the Communist Party and the Council of Ministers of the Soviet Union. The objective was to "develop a methodology for remote operation on an earthquake epicentre by using weak seismic fields and research possibilities of transferring the seismic energy of an explosion".

The documents say that the Mercury project involved 22 scientific and industrial organizations, including the Geological Institute of the Azerbaijan Academy of Sciences in Baku. The remit extended to developing the electronic equipment to be installed aboard space satellites that would control the tectonic weapon. The scientists were given three years to complete research, with testing planned for 1990 .

During the research phase, Azerbaijani scientists grew increasingly confident and, according to the documents, were sure that "after [a] nuclear explosion, subterranean energy may accumulate at huge distances from the epicentre and reach massive capacity, after which the next directed explosion can release it all".

Underground testing began at the town of Batken in Kyrgyzstan, and was directed by Ikram Kerimov, of the Azerbaijan Academy of Sciences. The documents say that scientists detonated an underground nuclear charge and tried to control the direction of seismic energy released using British-built equipment known as 'system 9690'.

A report prepared by the Mozhaisky Military Engineering Institute concluded that the test had been a success. But progress slowed considerably following Azerbaijan's independence from the Soviet Union. At about this time, Russia embarked on a more comprehensive tectonic warfare programme known as the Volcano project. The Earth Physics Institute of the Russian Academy of Sciences (RAS) became the project headquarters.

Research was scheduled to be completed in 1992, with underground testing beginning the following year. The final test was carried out at a place code-named S36NZ-0Kh; Moscow News believes the letters 'NZ' refer to Novaya Zemlya, where Soviet nuclear testing began in the 1950s. Carl Levitin

\section{Precautionary route for risk management backed by Chirac}

Paris. Jacques Chirac, the French president, said last week endorsed the "precautionary principle" in the management of risks associated with science and technology, as well as the promotion of ethical debate as a way of reconciling society with the changes brought about by such advances.

Chirac, speaking at the opening of the fourth annual meeting of Unesco's International Bioethics Committee in Paris, said

\section{IMAGE UNAVAILABLE FOR COPYRIGHT REASONS}

Chirac: ethical debate furthers understanding.

But he added that ethical debate does not remove decision-making responsibility from politicians, saying that the role of scientific experts is to give impartial advice, not to make decisions themselves. Referring to the 'mad cow affair', Chirac said he endorsed the precautionary principle in decision-making - that politicians should "not hesitate to favour the worst-case scenario" - whenever the potential consequences could be disastrous.
Declan Butler

\section{Italy joins call for more coordination}

Munich. The research programmes of the European Union (EU) should be more closely coordinated with the work of national research organizations, according to the Italian government. The proposal comes in Italy's position paper on the European Commission's fifth Framework research programme (FP5), which is due to begin in 1998 .

The paper reflects the influence of Antonio Ruberti, a former EU research commissioner, who heavily promoted the concept of cooperation and coordination with member states during his term of office in 1993-94. He is now head of the Italian parliament's committee on science and technology.

According to the paper, the commission should invoke articles in the Maastricht Treaty that allow it to support complementary research outside the main Framework programme that involves a limited number of member states. Such arrangements, known as 'variable geometry', also have the support of Germany and the Netherlands (see Nature 381, 634; 1996). They could either involve a 'top-down' initiative from the commission, or a 'bottom-up' initiative of two or more member states or national research organizations.

FP5 should concentrate on three main themes, the paper says: quality of life and environment, the information society, and sustainable production. It lists possible objectives within these areas, including development of vaccines, elucidation of the neurological basis of diseases of ageing, and future energy options, including nuclear fusion.

The Italian paper also includes a plea for the planned international fusion reactor, called ITER, to be sited in Europe - even though no European country has expressed a wish to host the reactor.

Alison Abbott 